微粒子活性炭によるリンパ節染色からみた

胃癌占居部位別郭清範囲の検討

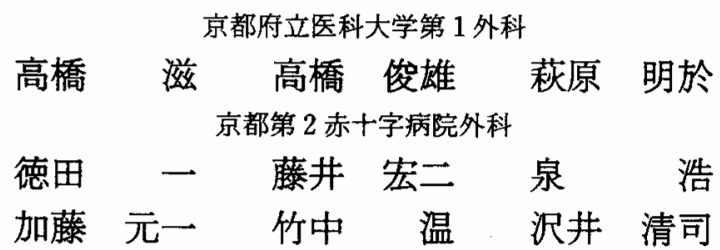

\title{
ACTIVATED CARBON PARTICLE (CH44) STAINING AS A MEANS TO DETERMINE THE EXTENT OF LYMPH NODE DISSECTION FOR METASTASIS FROM VARIOUS SITES OF CANCER IN THE STOMACH
}

\section{Shigeru TAKAHASHI, Toshio TAKAHASHI and Akeo HAGIWARA}

The First Department of Surgery, Kyoto Prefectural University School of Medicine

Hajime TOKUDA, Kouji FUJII, Hiroshi IZUMI, Gen-ichi KATO, Atsushi TAKENAKA and Kiyoshi SAWAI

Department of Surgery, Kyoto Second Red Cross Hospital

$\mathrm{R}_{3}$ 以上の郭清により根治切除された胃癌症例 123 例の5ち，65例で術前内視鏡下に胃癌周囲粘膜下 層に微粒子活性炭 CH44を注入し, 所属リンパ節を黑染し郭清を行った。これらにつき壁深達度別にリ ンパ節転移を検索し, 胃上部 (C) 癌と胃下部 (A) 癌で各リンパ節番号別に転移率・転移度拉よび肉 眼的黒染度を比較し, 郭清の方針につき以下の結果を得た。

1) CH44のリンパ指向性と実際の転移はよく一致して和り, en-bloc 郭清の指標として CH44はきわ めて有用であった。 2) 早期癌では $R_{2}$ 郭清が必要であり，A癌ではNo. (12)の重点郭清が望ましい，3） $\mathrm{pm}$ 胃癌では定型的 $R_{3}$ 手術が過不足のない手術と考兄られた．4）ss 以上の胃癌における腹部大動脈 周曲リンパ節 No. (16転移陽性例は23.3\%（17/73）と高率であり．No. (16)リンパ節の積極的な郭清を こころでみるべきであると考えられた。

实引用語：胃癌のリンパ節郭清，胃癌の壁深達度，胃癌の占居部位，腹部大動脈周囲リンパ節，微粒子活性炭 (CH44)

はじめに

リンバ節転移は胃癌予後因子のなかで最も重要な因 子の 1 つであり。胃癌根治手術ではその郭清範囲が問 題となる.現在多くの施設で早期癌には $\mathrm{R}_{2}$ 郭清 ${ }^{11}$, 進行 癌には拡大根治手術が施行されている。しかし正常り ンパ節をも広範に郭清することは生体防御機構の面か らも問題があることも事実である2). したがって個々 の胃癌症例において局所進展に応じた適切なリンパ節

$<1986$ 年 7 月 9 日受理 $>$ 別刷請求先：高橋 滋 干602 京都市上京区河原町通り広小路上儿梶井町465 京都府立医科大学第 1 外科
郭清を施行するのが理想と考えられるが，占居部位と 壁深達度に応じて郭清範囲を決定することは必ずしる 容易でなく, とくに腹部大動脈周囲リンパ節(以下 No. (16)と略す) 郭清の適応について論じた報告は少ない, しかしNo. (16)転移陽性例とい党ども郭清・切除するこ とにより長期生存が得られるとの報告すある。そこで 著者らは十分郭清されたと考えられる症例において壁 深達度とリンパ節転移の関係を検索し, 進行度に応じ たリンパ節郭清の範囲を検討した。ささらに微粒子活性 炭 (以下 $\mathrm{CH} 44$ と略す) を術前内視鏡下に胃癌周囲の粘

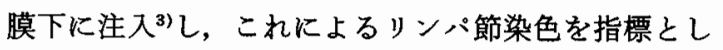


四 1 食道下部, 胃全剔を行った 1 症例の郭清リンパ 節. 数字はリンパ節番号で, 分類は黒染リンパ節数/ 郭清リンパ節数である. No (1), (7), (11)の転移リンパ 節も黒染されている。

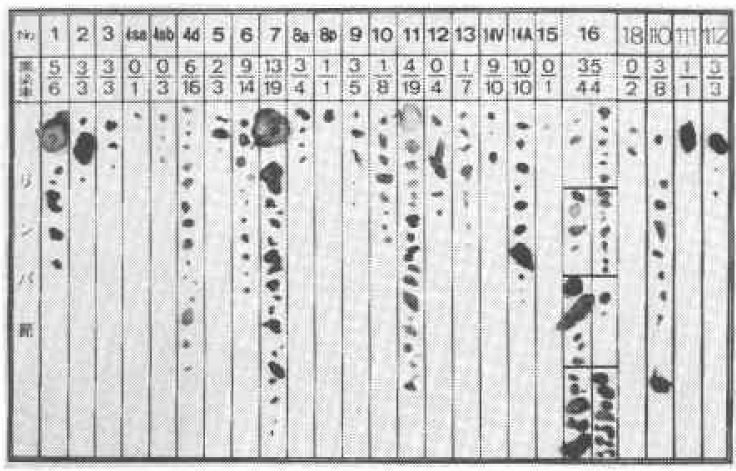

てリンパ節郭清を行うことの妥当性について郭清リン 八節の転移度と肉眼的黒染度から検討したので報告す る.

\section{対象と方法}

対象は京都第 2 赤十字病院外科において昭和 54 年 4 月から昭和 60 年 3 月までの 6 年間に $\mathrm{R}_{3}$ 以上の郭清に より根治切除された胃癌症例123例である.このうち65 例において萩原ら゙の開発した極めてリンパ指向性が 高い微粒子活性炭 $\mathrm{CH} 44$ (蒸留水 $1 \mathrm{ml}$ 中に径 $21 \mathrm{~m} \mu$ の ミツビシ \#44炭素50mg とポリビニルピロリドン $20 \mathrm{mg}$ をローリング法にて分散させ隇菌した炭素影濁液，以 下 CH44 と格す）を手術の 1 ～ 2 日前内視鏡下に胃癌 周囲粘膜下層 4 箅所に合計 $2 \mathrm{ml}$ 注入し, リンパ節郭清 を行い(図 1)，これを点墨群とした。胃癌取り扱い規 約 ${ }^{5)}$ に準じた占居部位別内訳は表 1 のごとくであっ た. 組織学的検索方法は胃癌取り扱い規約の作成方法 により切片を作成し, 顕徽鏡にて転移执よび黒染の有 無を判定した.そして下記の項目につき検索を行った。

1) 対象123例の $5 ち \mathrm{C}$ 癌27例, M癌42例, $\mathrm{A}$ 癌45例 で各所属りンパ節の番号別転移率(転移陽性症例数/郭 清総症例数) と転移度 (転移陽性りンパ節数/郭清総り ンパ節数）を比較した。

2）胃癌の壁深達度とリンパ節転移の関係を検索し た。とくにps (十)胃癌に拈けるNo. (16)転移陽性の程 度を検索した。点墨群65例の5ちC癌17例と A癌23例 のリンパ節番号別黑染度 (肉眼的黒染リンパ節数/郭清 総リンパ節数)を比較した。

3）胃癌の壁深達度とリンパ節転移の関係を検索し た. とくにps (十)胃癌に打けるNo. (16)転移陽性の程
表 1 各群における腫痬占居部位の内訳

\begin{tabular}{|c|c|c|}
\hline 占居部位 & 症 例 数 & 点 量 㪊 \\
\hline C & 27 & 12 \\
\hline M & 42 & 24 \\
\hline A & 45 & 23 \\
\hline CMA & 9 & 6 \\
\hline 部 & 123 & 65 \\
\hline
\end{tabular}

表 2 各占居部位における転移例数

\begin{tabular}{rrrrrr}
\hline 占居部位 & $n_{1}$ & $n_{2}$ & $n_{3}$ & $n_{4}$ & 計 \\
\hline$C(n=27)$ & 5 & 6 & 4 & 4 & 19 \\
\hline$M(n=42)$ & 10 & 3 & 6 & 3 & 22 \\
\hline$A(n=45)$ & 8 & 6 & 2 & 7 & 23 \\
\hline
\end{tabular}

度を検索した。

4）以上の結果をもとにC 癌と $\mathrm{A}$ 癌に和いて深達度 に応じた郭清範囲を検討した。

\section{結果}

123例に和ける占居部位別内訳はC 癌27例, M癌42 例， $\mathrm{A}$ 癌45例であり．表 2 のごとく各群のリンパ節転 移における進行度に差は認められなかった。また占居 部位別の転移度は括の括のC癌10.9\%(209/1915)，M 癌10.9\%(307/2823), A 癌10.9\%（268/2467）と差を 認めなかった．点墨群65例の占居部位別内訳は C癌 12 例， $\mathrm{M}$ 癌24例， $\mathrm{A}$ 癌23例であり。肉眼的黑染度はC 癌 $53.2 \%(771 / 1450), \mathrm{M}$ 癌50.2\% (1278/2548), $\mathrm{A}$ 癌 54.5\%（1061/1946）であり。有意差は認められなかっ た。

I 、C癌とA癌におけるリンパ節番号別にみた転移 率・転移度之肉眼的黑染度の相関

1) 第 1 群リンパ節 (No. (1)～(6)

C 癌の転移率は, No. (1) $(32.0 \%) \cdot N o$. (2) $(17.4 \%) \cdot$ No. (3) $(56.0 \%)$, No. (4sa) $(13.3 \%) \cdot$ No. (4sb) $(20.0 \%)$ に沶いてA癌より高かった。本た転移度 でも No. (1) $(12.3 \%) \cdot$ No. (2) $(17.4 \%) \cdot$ No. (3) $(23.2 \%) \cdot N o$. (4sa) $(7.7 \%) \cdot N o$. (4sb $(5.7 \%)$ に扎 てA癌より高く, No. (2)と(3)で有意差を認めた（p< 0.005).さらにCH44によるC癌の肉眼的黑染度は, No. (1) $(65.6 \%) \cdot$ No. (2) $(63.3 \%) \cdot$ No. (3) $(74.0 \%) \cdot N o$. (4Sb) (27.5\%) に拈いて有意に高く（p< 0.05)，転移率执よび転移度の結果とよく一致してい た。これに対し，A癌の転移率は，No. (4d) (28.9\%)・ No. (5) $(15.4 \%) \cdot$ No. (6) $(40.0 \%)$ でC癌より高く, 転移度でも同様に，No. (4d) $(14.1 \%) \cdot N o$. (5) 
表 $3 \mathrm{C}$ 癌， M癌， $\mathrm{A}$ 癌に和けるリンパ節番号別転移 率 $(\%)$

\begin{tabular}{|c|c|c|c|}
\hline ノンパ節番号 & $C(n=27)$ & $M(n=43)$ & $A(n=45)$ \\
\hline (1) & $32.0(8 / 25)$ & $20.5(8 / 39)$ & $17.2(5 / 29)$ \\
\hline (2) & $17.4(4 / 23)$ & $14.3(4 / 28)$ & $3.9(1 / 26)$ \\
\hline (3) & $56.0(14 / 25)$ & $50.0(15 / 30)$ & $26.8(11 / 41)$ \\
\hline (4se) & $13.3(2 / 15)$ & $20.0(2 / 10)$ & - \\
\hline (4sb) & $20.0(3 / 15)$ & $4.2(1 / 24)$ & $0.0(0 / 26)$ \\
\hline (40) & $15.4(4 / 26)$ & $26.2(11 / 42)$ & $28.9(13 / 45)$ \\
\hline (5) & $4.6(1 / 22)$ & $7.7(3 / 39)$ & $15.4(6 / 39)$ \\
\hline (6) & $3.7(1 / 27)$ & $27.5(11 / 40)$ & $40.0(18 / 45)$ \\
\hline (7) & $30.8(8 / 26)$ & $27.5(11 / 40)$ & $22.0(8 / 37)$ \\
\hline (8a) & $20.0(5 / 25)$ & $13.8(5 / 36)$ & $15.4(6 / 39)$ \\
\hline (8D) & $16.7(1 / 6)$ & $0.0(0 / 14)$ & $5.9(1 / 17)$ \\
\hline (9) & $12.0(3 / 25)$ & $19.2(5 / 26)$ & $24.1(7 / 29)$ \\
\hline (19) & $19.2(5 / 26)$ & $11.1(2 / 18)$ & - \\
\hline (11) & $25.0(6 / 24)$ & $20.6(7 / 34)$ & $10.8(4 / 37)$ \\
\hline 12 & $0.0(0 / 16)$ & $3.3(1 / 30)$ & $10.8(4 / 37)$ \\
\hline (13) & $0.0(0 / 18)$ & $18.2(4 / 22)$ & $6.1(2 / 33)$ \\
\hline (i4) & $27.3(3 / 11)$ & $0.0(0 / 17)$ & $9.1(2 / 22)$ \\
\hline (16) & $17.1(3 / 21)$ & $10.4(3 / 29)$ & $18.4(7 / 38)$ \\
\hline
\end{tabular}

表 $4 \mathrm{C}, \mathrm{A}$ 癌に括けるリンパ節番号別転移度と肉眼 的黒染度 (1)

\begin{tabular}{|c|c|c|}
\hline \multirow{2}{*}{ リンバ算番号 } & \multicolumn{2}{|c|}{ 占居 部 位 } \\
\hline & c & A \\
\hline (1) & $12.3(22 / 179)$ & $6.3(5 / 80)$ \\
\hline (2) & $17.4(15 / 86)$ & $2.7(2 / 74)$ \\
\hline (3) & $23.2(38 / 164)$ & $8.2(23 / 244)$ \\
\hline 4 sa & $1.7(3 / 39)$ & $0.0(0 / 7)$ \\
\hline 4 sb & $5.7(4 / 70)$ & $0.0(0 / 57) \ldots$ \\
\hline (4d) & $6.0(10 / 167)$ & $14.1(42 / 298) \ldots$ \\
\hline (5) & $3.2(2 / 62)$ & $16.5(17 / 103) \ldots *$ \\
\hline (6) & $1.9(2 / 103)$ & $24.2(71 / 293)$ \\
\hline \multicolumn{3}{|l|}{ 肉眼的黒染度 (x) } \\
\hline 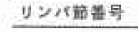 & c & A \\
\hline (1) & $65.6(82 / 125)$ & $27.1(19 / 70) \ldots$ \\
\hline (2) & $63.3(38 / 60)$ & $37.0(20 / 54) \ldots$ \\
\hline (3) & $74.0(100 / 135)$ & $52.1(114 / 219) \ldots$ \\
\hline 4 se & $11.6\left(5^{/ 43}\right)$ & $12.5(1 / 8)$ \\
\hline 4 sb) & $27.5(19 / 69)$ & $12.2(6 / 49) * * *$ \\
\hline (4d) & $27.4(37 / 135)$ & $53.4(156 / 292)$. \\
\hline (5) & $20.5(8 / 39)$ & $51.4(38 / 74)$. \\
\hline (6) & $36.7(22 / 60)$ & $72.1(124 / 172) \cdot$ \\
\hline
\end{tabular}

(16.5\%)・No. (6) (24.2\%) においてC癌より高く， すべて有意差を認めた $(\mathrm{p}<0.05)$, 黒染度も No. (4d (53.4\%)・No. (5) (51.4\%)・No. (6) (72.1\%) でC癌 より有意に高く $(\mathrm{p}<0.005)$ ，転移率および転移度の結 果と一致していた（表 3,4）.

2) 第 2 群リンパ節 (No. (7)〜 (11))

C 癌の転移率は, No. (7) $(30.8 \%) \cdot N o$. (8a) $(20.0 \%) \cdot$ No. (10) $(19.2 \%) \cdot$ No. (11) $(25.0 \%)$ でA癌 より高く，転移度は，No. (7) (14.5\%)・ No. (10) $(8.8 \%) \cdot$ No. (11) $(13.6 \%)$ でA癌より高く, No. (7) (11)で有意差を認めた $(\mathrm{p}<0.02)$, A癌の転移率は, No.
表 $5 \mathrm{C}, \mathrm{A}$ 癌に括けるリンパ筋番号別転移度と肉眼 的黒染度 (2)

\begin{tabular}{|c|c|c|}
\hline \multirow{2}{*}{ リンパ筑番号 } & \multicolumn{2}{|c|}{ 占居 部 位 } \\
\hline & c & A \\
\hline (7) & $14.5(19 / 131)$ & $4.7(16 / 343)$ \\
\hline (8a) & $9.0(7 / 78)$ & $12.4(18 / 145)$ \\
\hline (9) & $6.9(5 / 73)$ & $16.7(17 / 102) \ldots$ \\
\hline (10) & $8.8(11 / 125)$ & $0.0(0 / 1)$ \\
\hline (ii) & $13.6(30 / 221)$ & $4.1(5 / 116) * *$ \\
\hline \multicolumn{3}{|c|}{ 肉䀶的黑染度 (X) } \\
\hline 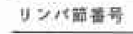 & c & A \\
\hline (7) & $69.2(72 / 104)$ & $70.1(141 / 201)$ \\
\hline (80) & $44.9(22 / 49)$ & $63.5(66 / 104)=$ \\
\hline (9) & $58.0(40 / 69)$ & $67.4(31 / 46) \ldots \ldots$ \\
\hline (10) & $31.4(22 / 70)$ & - \\
\hline (11) & $47.7(62 / 130)$ & $33.9(37 / 109) * *$ \\
\hline$\cdot p<0.005$ & $p<0.05 \quad \cdots$ & \\
\hline
\end{tabular}

(9) $(24.1 \%)$ で高く,転移度は, No. 8a $(12.4 \%) \cdot$ No.

(9) (16.7\%) においてC癌より高かったが有意差は認 められなかった。肉眼的黒染度は，C癌ではNo. (11) (47.7\%) でA癌より有意に高く，A癌ではNo. 8a $(63.5 \%) \cdot(9)(67.4 \%)$ でC癌より高かった（表 5$)$.

3）第 3 群リンパ節（(8D)・(12)・(13)

C癌の転移率は, No. 8D (16.7\%)でA癌にくらべ て高く，転移度もC癌（28.1\%）でやや高かった。肉 眼的黒染度はC 癌 $(51.5 \%)$ と 癌 $(55.7 \%$ ) で有意 差を認めなかった。 A 癌の転移率は, No. (12) $(10.8 \%) \cdot$ No. (13) $(6.1 \%)$ でC癌より高く, No. (12)で 有意差を認めた $(\mathrm{p}<0.05)$. また肉眼的黒染度も No. (12) $(40.4 \%) \cdot$ No. (13) (37.3\%) で高かった（表 6).

4）第 4 群リンパ節 (No. (144)・ (16))

C 癌の転移率は, No. (14A $(27.3 \%)$ でややA癌より 高く, 転移度 $(8.5 \%)$ - 肉眼的黒染度 $(71.4 \%)$ 6同 様であったが，C癌と $\mathrm{A}$ 癌に拈打きな義はなかった。 No. (16)転移率はM癌 (10.4\%) でやや低いが，C癌 (17.1\%) とA癌 (18.4\%) に有意差は認められず，転 移度も同様であった。一方肉眼的黑染度は C癌 $74.3 \% \cdot \mathrm{A}$ 癌 $63.0 \%$ と有意差は認めるが $(\mathrm{p}<0.05)$, いずれの領域でもきわめて高かった。

II. 壁深達度とリンパ節転移の関俰

壁深達度別にリンパ筋転移を表 7 のごとく群別にみ ると, $\mathrm{m} \cdot \mathrm{sm}$ 癌では $92.6 \%(25 / 27)$ が $\mathrm{n}(-)$ 症で, $\mathrm{n}(+) の 2$ 例は $\mathrm{n}_{1}(+)$ であった. $\mathrm{pm}$ 癌のリンパ節 転移陽性は $52.2 \%(12 / 23)$ で, このうち 4 例 (17.4\%) 
表 $6 \mathrm{C}, \mathrm{A}$ 癌に和けるリンバ節番号別転移度と肉眼 的黒染度 ( 3 )

\begin{tabular}{|c|c|c|}
\hline \multirow{2}{*}{ リンパ箇番号 } & \multicolumn{2}{|c|}{ 占居部位 } \\
\hline & c & A \\
\hline (8p) & $28.1(9 / 32)$ & $19.1(4 / 21)$ \\
\hline (12) & $0.0(0 / 55)$ & $7.5(12 / 160) *$ \\
\hline (13) & $0.0(0 / 25)$ & $2.2(2 / 93)$ \\
\hline (19) & $8.5(4 / 47)$ & $6.1(5 / 82)$ \\
\hline (16) & $11.0(28 / 254)$ & $11.3(32 / 263)$ \\
\hline
\end{tabular}

\begin{tabular}{|c|c|c|}
\hline リンパ節番号 & c & A \\
\hline (8P) & $51.5(17 / 33)$ & $55.7(49 / 88)$ \\
\hline (12) & $12.5(2 / 16)$ & $40.4(38 / 94) *$ \\
\hline (13) & $27.8(5 / 18)$ & $37.3(22 / 59)$ \\
\hline (14) & $71.4(30 / 42)$ & $65.6(40 / 61)$ \\
\hline (16) & $74.3(188 / 253)$ & $63.0(160 / 254) *$ \\
\hline
\end{tabular}

表 7 胃癌壁樑達度別にみた転移率（\%）

\begin{tabular}{|c|c|c|c|c|c|c|}
\hline 深 浩 & 应胡数 & $n_{0}$ & $\mathrm{n}_{4}$ & $p_{r}$ & nis. & $\pi \cdot$. \\
\hline m. sm & 27 & 92.6 & 7.4 & 0.0 & 0.0 & 0.0 \\
\hline pm & 23 & 47.8 & 30.4 & 4.4 & 17.4 & 0.0 \\
\hline ss $\alpha, \beta$ & 8 & 50.0 & 37.5 & 12.5 & 0.0 & 0.0 \\
\hline ss $r$, sei & 65 & 15.4 & 21.5 & 23.1 & 13.8 & 26.2 \\
\hline
\end{tabular}

表 8 PS (十) 症例に括ける占居部位別群別転移率 (\%)

\begin{tabular}{ccccccc}
\hline 占居部位 & 症例数 & $\mathrm{n}_{3}$ & $\mathrm{n}_{1}$ & $\mathrm{n}_{3}$ & $\mathrm{n}_{3}$ & $\mathrm{n}_{4}$ \\
\hline $\mathrm{C}$ & 17 & 5.9 & 11.8 & 35.3 & 23.5 & 23.5 \\
\hline $\mathrm{M}$ & 17 & 29.4 & 29.4 & 11.8 & 11.8 & 17.7 \\
\hline $\mathrm{A}$ & 22 & 18.2 & 18.2 & 22.7 & 0.1 & 31.8 \\
\hline $\mathrm{CMA}$ & 9 & 0.0 & 33.3 & 22.2 & 11.1 & 33.3 \\
\hline It & 65 & 15.4 & 21.5 & 23.1 & 13.8 & 26.2 \\
\hline
\end{tabular}

は $\mathrm{n}_{3}(+)$ 症例であったが, No. (16) (十) 症例は認め られなかった. $\mathrm{s} \alpha$ 以上の胃癌のらち $\mathrm{n}_{3}(+)$ または No. (16) (十) 症例は35.6\% (26/73) であった。しかし ps（一)ではNo. (16) (+) 症例は認められず, No. (16) (十) 症例はすべて ps $(+)$ 胃癌であった. 123例中 ps (十)65症例で占居部位別に No. (16)転移率をみると，表 8 のごとくC 癌23.5\% (4/17), M癌17..7\% (3/17), $\mathrm{A}$ 癌 $31.8 \%$ (7/22), CMA 癌33.3\% (3/9)で, いずれ
の占居部位でも No. 10（十）症例が認められた.

\section{考 察}

胃癌の手術に扔いて, 壁深達度と占居部位からどの 程度のリンパ節郭清を行うべきか, 現在統一した見解 は得られていない。とくにPS (一) 症例では広範な en-bloc 郭清がよりよい遠隔成績につながると思われ るが、リンパ節が癌のリンパ行性転移の barrier にな るとの説もあり，一律に広範郭清を行うことは問題で ある。一方画像診断の進歩により，個々の胃癌症例に 扣ける深達度和扣よび所属りン八節転移の術前診断》 が可能になりつつあるが, 術前にリンパ節転移を正確 に診断するのは困難であり，術前・術中所見の総合判 断から適切なリンパ節郭清を行らのが望ましい，それ ゆえに著者らは, 術前内視鏡下に胃癌周囲の粘膜下に CH44を注入することにより所属リンパ節を染色し, 占居部位別リンバ流および転移の相関を検索し, さら に壁深達度とリンパ節転移の関係から必要な郭清範囲 はどこまでかを検討した。また CH44を指標として重 点郭清を行うことの妥当性について郭清りンパ節の転 移度と黑染度から検討した。

I．CH44を指標としたリンパ節郭清の意義

色素を胃壁内に注入しリンパ節郭清の指標とするこ ころみは，1950年 Weinberg ${ }^{\mathrm{B}}$ 飞始まり，墨汁を術前内 視鏡下に胃癌周囲粘膜下層に注入し, 郭清の指標とす るこころみは落合・大同ら”が有用であると報告して いる. 石傳ら ${ }^{10}$ はペリカンインクを用い, 胃癌占居部位 別のリンパ流について詳細な報告をしているが，いず れも第 3 群リンパ節の黒染による報告であった。一方 萩原らの開発した $\mathrm{CH} 44$ は沢井ら ${ }^{11}$ の報告にもあるよ 5 KNo. (16)る短時間のらちに高率に黒染する特徵 を有し，極めて指向性が高い，著者らは各りンパ節番 号別に転移率・転移度招よび肉眼的黒染度をC癌と $\mathrm{A}$ 癌で比較したところ，CH44のリンパ指向性と実際の 転移の方向は第 4 群にいたるまでよく一致していた。 すなわち第 1 群りンパ節に怙いては転移率, 転移度と 肉眼的黒染度はよく相関し，CH44によるリンパ節の 黒染は胃癌占居部位別リンパ流拈よび転移の方向を示 す指標として有用と考号られた。第 2 群リンパ節に招 いてはNo. (7)・(8a)・(9)では黒染度はC癌の No. 82)以 外いずれも $60 \%$ 以上と高く, 転移度も No. (7)で有意差 を認める以外には統計学上差を認めず, これらNo. (7)，8a，(9)では占居部位によらずリンパ流量が豊富で あり，十分な郭清が必要と考克られた。また No. (10)・ (11)ではNo. (7)・(8a)・(9)リンパ節に対し黒染度・転移度 
表 9 転移有無別組織学的黒染度（\%)

\begin{tabular}{|c|c|c|}
\hline & 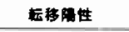 & 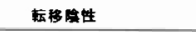 \\
\hline 第 1 啸 & $53.6(50 / 113)$ & $59.9(214 / 357)$ \\
\hline 第 2 群 & $52.1(50 / 96)$ & $66.7(188 / 282) p<0.05$ \\
\hline 第3 神 & $33.3(2 / 6)$ & $60.0\{63 / 105\}$ \\
\hline 第4 群 & $44.2(50 / 113)$ & $56.0(117 / 209)<<0.05$ \\
\hline
\end{tabular}

(全时 10 和)

とも低い傾向を認めるが，C癌では黒染度・転移度と も比較的高く，胃体上部のリンパ流は豊富と考えられ た。ささらにC癌では, No. (10)・(111胃癌取り扱い規約 の第 2 群であるが, 第 1 群である No. (4s92)(4sb)リンパ節 より黒染度・転移度とも高く, 注意が必要之考えられ た。また No. (11はA 癌でも転移率は $10.8 \%$ ・転移度 4.3\%・肉眼的黒染度 $33.9 \%$ であり，A 領域からむかな りのリンパ流が存在することがわかった。第 $3 \cdot 4$ 群 リンパ節では, $\mathrm{C} ・ \mathrm{~A}$ 癌の黒染度・転移度をみると, 従 来第 3 群とされているNo. (12)・(13)の黒染度・転移度は, No. (144)・(16)リンパ節よりも低かった。 したがって胃の リンパ流は, 病巣の占居部位によっては第 3 群よりも 第 4 群へ豊富に流れていることがわかった。 また胃全 摘10例において郭清されたりンパ節の組織学的黒染度 を転移の有無別に第 1 症から第 4 群にわけて比較し, CH44を指標として重点郭清を行らことの妥当性につ いて検討した。結果は表 9 のごとく転移陰性リンパ節 の黒染度は64.8\% (546/842) で，転移陽性のリンパ節 の黒染度は52.6\% (162/308) であった。このことは, 癌の転移が高度となりリンパ管の閉塞が扔こると，そ の部位以下は染色されにくいが，転䔟高度のリンパ節 は腫大すると推察され, 術前・術中所見で識別が可能 と考觉られた。またリンパ節に小転移巣が存在してい ても，CH44により黒染されるため，転移の有無によら ず，郭清を容易にするすのと考劣られた，以上 $\mathrm{CH} 44$ は, en-bloc 郭清の指標としてきわめて有用と考兄ら れた。

II. 壁深達度とリンパ節転移からみた郭清範囲の検 討

1) $\mathrm{m} \cdot \mathrm{sm}$ 癌

早期癌のリンパ節転移率は, 三輪ら ${ }^{12)}$ による $\mathrm{m}$ 癌 $6.6 \% \cdot \mathrm{sm}$ 癌 $23 \%$ であり, $\mathrm{m} \cdot \mathrm{sm}$ 癌とも $\mathrm{n}_{3}(+) \cdot \mathrm{n}_{4}$ (十)例を少数ながら認めるとしている。また高木ら ${ }^{13)}$ はリシパ節転移を $18.1 \%(69 / 382)$ に認め, 群別にみ ると $\mathrm{n}_{1}(+) 10.0 \% \cdot \mathrm{n}_{2}(+) 5.7 \%$ と大部分が $\mathrm{n}_{2}$ までに 存在するが, $n_{3}(+)$ が 4 例, $n_{4}(+)$ が 1 例認められた
と報告している，著者らの症例では $\mathrm{n}_{3}(+) \cdot \mathrm{n}_{4}(+)$ 例 は認められず, $\mathrm{m} \cdot \mathrm{sm}$ 癌では少なくとも $\mathrm{R}_{2}$ 郭清が必要 と考学られた ${ }^{14)}$. さらにCH44による肉眼的黒染度お よび転移度からみて，A癌ではNo. (12)・(13)へのリンパ 流が比較的豊富であり, 少なくとも No. (11)を深達度に 沁して重点的に郭清することによりほぼ分な郭清が 可能と考えられた。 またC癌ではNo. (11) $(47.7 \%)$ と No. (10) (31.4\%) が黒染されやすく, リンパ流が豊富 であると考兄られる。大森ら ${ }^{(5)} は$ 胃上部の早期癌の No. (11)の転移率は1.7\%であったが，No. (10)への転移 は認められなかったと報告している。これに対し著者 らの経験した123例に括いて, m・sm 癌ではNo. (10)・(11) の転移は認められなかった。 またNo. (10)・(11)を完全に 郭清するには脾・膵体尾部合併切除術が必要であるが, 神代ら ${ }^{16)}$ は No. (10)に転移のない症例では脾温存手術 のほうが予後は良好であったと報告しており，この点 からも C 領域の早期癌では脾・满体尾部合併切除術の 意義は少ないと考えられた。

2) $\mathrm{pm}$ 癌

$\mathrm{pm}$ 癌の転移率をみると，三宅ら ${ }^{17}$ は $48.5 \%$ に転移 を認め, 群別では $\mathrm{n}_{1}(+) 33.3 \% \cdot \mathrm{n}_{2}(+) 15.1 \%$ とし ている，友清ら ${ }^{18)}$ は46\%に転移を認め，群別では $\mathrm{n}_{1}$ (+) $32 \% \cdot n_{2}(+)$ 以上 $14 \%$ と報告している．著者らの 症例では $\mathrm{n}(+)$ 例は $52.5 \%$ と諸家の報告にくらべ高率 であり，とくに $\mathrm{n}_{2}(+)$ または $\mathrm{n}_{3}(+)$ 例が $21.7 \%$ と高 率であった。 $\mathrm{pm}$ 癌では $\mathrm{n}_{4}(+)$ 症例は認められなかっ た。

以上から $\mathrm{pm}$ 胃癌では定型的 $\mathrm{R}_{3}$ 手術が過不足のな い手術之考光られた。亦たC癌に㧊いてNo. (10)・(11)の 郭清の適応は現在もを子まった見解は得られていない るのの, 中島ら ${ }^{199}$ は No. (11)の転移を連関測度 $y$ から 検討し, 術中 No. (2)・(3)の転移状況に応じて郭清すべ きであるとしている．著者らの報告した123例中 No， (11)転移陽性例は19例であり，らち No. (2)に転移を認め たものは47.4\%で，No. (3)に転移を認めたものは $79.0 \%$ ，No. (3)または(7)に転移を認めたるのは $89.5 \%$ であった. また No. (11)への単独転移例は $10.5 \%$ と少数 ながら存在していた. 単独転移例はいずれる $\mathrm{MC}$ 領域 の pm 癌であった. 以上から胃体上部癌ではNo. (2)の samplingによる迅速組織診を施行し，No. (2)・(3)また は(7)に転移を認めた場合胃全摘術20)特よび脾・腪体尾 部合併切除術が必要と考えられた。また CH44による 検索からA癌でも No. (11)郭清の必要性が示唆された。

3） $\mathrm{ss \sim}$ 癌 
ss 以上の胃癌における No. (16（）例は73例中17例 （23.3\%）を占め，また切離された123例中C 癌 $23.5 \%$ (4/17), M癌 $17.7 \%(3 / 17), \mathrm{A}$ 癌 $31.8 \%(7 / 22), \mathrm{CMA}$

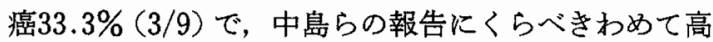
率であった。また著者らの経験したNo. 16転移陽性例 の深達度はすべて ps(+)であり, ps(+)胃癌の $26.2 \%$ を占め, 高い比率であった。大橋ら (1) $^{2}$ No. (16)転移陽 性例飞 $\mathrm{R}_{3}+$ No. (16)郭清を施行し， 9.7\%の 5 生率を得 ており，積極的郭清より長期生存が期待しらるとのべ ている. 著者らは, ss 以上の進行癌で $\mathrm{H}_{0}$ の症例に No. (144)・(16)をふくむ徹底郭清（No. (16)は横隔膜直下ょり下 腸間膜動脈根部の高さむで郭清した。）を施行してい る. 123例のうち No. (16)(+)例は19例であり， 5 年経 過例は 4 例, 5 年生存例は 2 例と少ないが，累積 5 年 生存率 $24.3 \%$ を得ている. 以上から ss 以上の進行癌で $\mathrm{H}_{0}$ 症例に No. (14A)・(16)るくむ徹底郭清を施行する意 義があると考兄られた。

\section{まとめ}

京都第 2 赤十字病院外科に招いて $\mathrm{R}_{3}$ 以上の郭清に より根治切除された胃癌症例123例のうち, 65例で微粒 子活性炭 $\mathrm{CH} 44$ により所属りンパ節を黒染し郭清を 行った。これらにつき壁深達度別にリンパ節転移を検 索し，さらに転移と黒染の関係から郭清の方針につき 以下の結果を得た。

1）CH44のリンパ指向性と実際の転移はよく一致 して㧊り, en-bloc 郭清の指標として CH44は極めて有 用であった。

2）早期癌では $\mathrm{R}_{2}$ 郭清が必要であり，A癌では, No. (12)の転移率は $10.8 \%$ と高く, No. (12)の重点郭清が望ま ᄂい.

3） $\mathrm{pm}$ 胃癌では $\mathrm{n}_{2}(+)$ 李たは $\mathrm{n}_{3}(+)$ 例が $21.7 \%$ と 高率であるが， $\mathrm{n}_{4}(+)$ 症例は認められなかった。した がって pm 胃癌では定型的 $\mathrm{R}_{2}$ 手術が過不足のない手 術と考党られた。

4）ss 以上の胃癌に括ける腹部大動脈周囲リンパ節 No. (16)転移陽性例は $23.3 \%(17 / 73)$ と高率であり, No. (16)ンンハ節の積極的な郭清をこころみるべきであると 考兄られた。

\section{文献}

1）古河 洋, 平塚正広, 岩永 剛：治療方針と治療成 績の变遷。消外セミナー $20: 90-99,1985$

2）高橋俊雄, 西岡文三, 河野研一：リンパ節転移形成 における癌細胞の定量と增殖. Med Postgrad
$12: 454-458,1974$

3）高橋俊雄, 萩原明於：胃癌化学療法と内視鏡. 東 京, 蟹書房, 1983, p129-139

4）萩原明於：活性炭吸着マイトマイシン製剂の開発 とその臨床応用のための基礎的研究. 秋田医 $10: 187-229,1983$

5）胃癌研究会編：外科・病理・胃癌取扱い規約。改訂 第11版，東京，金原出版，1984

6）東 健, 沢井清司, 徳田一ほか：血管造影に上 る陥凹型早期胃癌類似進行癌の深達度診断. 日外 会誌 $86: 819-827,1985$

7) 竹中 温, 沢井清司, 徳田一汪か：胃癌の術前 STAGE 診断一超音波断尿法及び血管造影法を併 用して一。臨外 $40: 119-125,1985$

8) Weinberg J, Greaney EM: Identification of regional lymphonodes by means of a visual stating dye during surgery of gastric cancer. Surg Gynecol Obstet $90: 561-567,1950$

9）大同札二郎，落合準三：経管的色素注入によるリ ン八゚節染色について. 手術 $21: 799---804,1967$

10）石傳秀勝, 服部龍夫, 三浦 橎：胃癌のリンパ節染 色からみた郭清範囲の検討一内視鏡的に胃壁内墨 汁注入による一。外科診療 $3: 257-263,1976$

11）沢井清司, 高橋 滋, 高橋俊雄ほか：胃癌リンパ節 郭清の指標としての微粒子活性炭 ( $\mathrm{CH} 44)$ 術前内 視鏡下注入の有用性. 日消外会誌 $18: 912-917$, 1985

12）三輪 潔：早期胃癌の遠隔成績とその問題点，西 満正, 間島 進, 戸部隆吉ほか編, 現代外科学体系, 年刊追補, $77 \mathrm{c}$, 東京, 中山書店, $1977, \mathrm{p} 56-69$

13）高木国夫, 大橋一郎, 高橋 孝はか：早期胃癌の問 題点. 外科診寮 $34: 61-68,1976$

14）高橋俊雄, 小玉雅志, 木田光一注か：早期胃癌のリ ンパ節郭清。外科診療 $25: 163-168,1983$

15）大森幸夫, 本田一郎：噴門癌の臨床的特徵. 消外 $6: 1417-1422,1983$

16）神代龍之介, 玉田一郎, 井口 潔：胃癌手術に打け る摘脾について。消外 $6: 1833-1836,1983$

17）三宅政房：固有筋層 (pm) 胃癌の肉眼型とリンパ 行性転移に関する検討. 順天堂医 $22: 389-413$, 1976

18）友清 明：pm 胃癌の臨床病理学的検討一とくに sm 浸潤の大きさからみた予後を中心に一. 日消外 会誌 $14: 1549-1558,1981$

19）中島聡総，高木国夫，暒谷 鐶注：連関測度 $\gamma$ を指標とした胃癌のリンパ節転移パターンと郭清 法の検討. 臨外 39：1589-1597, 1984

20）三隅厚信, 青木正信, 吉中一郎㳗吕：噴門癌の外科 治療に扔ける問題点一近測胃切除術之胃全摘術の 比較. 日消外会誌 $17: 6-14,1984$

21）大橋一郎, 高木国夫, 暒谷 銀㳗か：胃澏に拈ける 大動脈周囲りンバ節転移例の 5 年生存例につい て. 日消外会誌 $9: 112-116,1976$ 